\title{
Tendências religiosas entre a população universitária: um estudo de caso
}

\author{
Religious trends among the university population: a case study
}

\author{
Pedro de Assis Ribeiro de Oliveira* \\ Roberlei Panasiewicz**
}

\begin{abstract}
Resumo
A religião continua a atrair a atenção das pessoas na sociedade brasileira atual. 0 pluralismo e o trânsito religioso parecem estar presentes no mercado de bens simbólicos da atualidade. Aqui convivem afeição e desafeição às instituições religiosas. E, especificamente no meio universitário, como as religiões estão presentes? Significam algo em suas vidas? $\mathrm{O}$ artigo analisa as respostas de 1446 estudantes de graduação da PUC Minas a um questionário sobre sua vida pessoal e acadêmica, tendo por objeto a dimensão religiosa. Os resultados são apresentados em dois momentos: uma visão global da religião na juventude universitária, e um estudo comparativo de católicos e evangélicos. Tópicos de destaque são: afiliação religiosa; ciclo da religião na biografia; educação e participação religiosa; aquisição de conhecimentos; avaliação de crenças, prescrições e lideranças; diversidade religiosa e influência na vida pessoal e profissional. A análise constata o apreço pela religião mesmo no ambiente laico do mundo universitário e aponta a confiança nos líderes religiosos como principal elo de ligação entre os estudantes e a instituição religiosa a que se refere sua fé.
\end{abstract}

Palavras-chave: Religião. Estudantes. Diversidade religiosa. Pertença. Liderança religiosa.

\begin{abstract}
Religion continues to attract people's attention in the current Brazilian society. Pluralism and religious transit seem to be present in today's market for symbolic values. Here live affection and disaffection to religious institutions. And specifically in the university environment, how religions are present? Mean something in their lives? This article analyzes the answers of 1446 undergraduate students of PUC-Minas to a questionnaire about their personal and academic life, with focus on the religious dimension of their life. The results are presented in two stages: an overview of religion among university students, and a comparative study of catholic and evangelical youth. Featured topics are: religious affiliation; cycle of religion in biography; education and religious participation; acquisition of knowledge; evaluation of beliefs, prescriptions and leaders; religious diversity and influence on personal and professional life. The analysis emphasyses the appreciation of religion even in secular environment of academia and points the trust in religious leaders as the main link between the students and the religious institution referred to their faith.
\end{abstract}

Keywords: Religion. Students. Religious diversity. Belonging. Religious leadership.

Artigo submetido em 08 nov. 2014 e aprovado em 16 dez. 2014. Pesquisa realizada com apoio do CNPq e FIP PUC Minas.

* Doutor em Sociologia (Louvaina, Bélgica), pesquisador do ISER-Assessoria e do Centro Fé e Política Dom Hélder Câmara, professor aposentado da UFJF e da PUC Minas. País de origem: Brasil. E-mail: pedror.oliveira@uol.com.br

** Doutor em Ciência da Religião pela Universidade Federal de Juiz de Fora. Coordenador e professor do Programa de Pós-Graduação em Ciências da Religião da Pontifícia Universidade Católica de Minas Gerais. País de origem: Brasil. E-mail: roberlei@pucminas.br 


\section{Introdução}

$\mathrm{O}$ ingresso na universidade marca um momento crucial na biografia da pessoa, principalmente se ele coincide com o "kairós da transição do 'pequeno mundo' adolescente e familiar para o 'grande mundo' social”. (RIBEIRO JÚNIOR, 2012. p. 235). A realidade do "pequeno mundo" vivido no âmbito familiar até o final da adolescência é então confrontada à realidade da universidade cuja função é abrir as portas do e da estudante para o "grande mundo" da sociedade ${ }^{1}$. Esse confronto de realidades põe em questão a plausibilidade (BERGER; LUCKMANN, 1978. p. 126-172) dos esquemas de pensamento, valores e comportamentos adquiridos no âmbito familiar. É evidente que isso inclui a religiosidade - pendor humano para a experiência do transcendente. A reação de cada religião - como expressão institucionalizada daquele pendor inato - será diferente.

Nesse artigo são examinadas algumas dessas reações que se expressam nas diferentes formas que a juventude universitária encontra para expressar sua relação com o divino, o misterioso, o transcendente ou espiritual ${ }^{2}$.

Seus dados advêm de uma pesquisa desenvolvida com estudantes matriculados na graduação da PUC Minas no segundo semestre de 2013, da qual participaram 1446 jovens, compondo uma amostra com índice de confiabilidade de $95 \%$ e margem de erro entre 2,5 e $5 \%$. A coleta de dados aconteceu online, através de link do Serviço de Gestão Acadêmica - SGA PUC Minas e a escolha da amostra foi sorteada a partir dos dados da Gerência de Tecnologia da Informação (GTI) da PUC Minas. Esses estudantes sorteados receberam o convite para participar da pesquisa. Responderam positivamente 797 do sexo feminino e 635 do sexo masculino. Como 14 estudantes não responderam a questão referente ao sexo, suas

\footnotetext{
${ }^{1}$ Para facilitar a leitura, não seguimos as normas de gênero e deixamos o plural no masculino, embora sabendo que a maioria (58\%) das pessoas que responderam ao questionário são do sexo feminino.

2 É impossível encontrar uma única palavra que dê conta das realidades a que se referem as pessoas religiosas. Usamos indiferentemente uma dessas quatro porque, por não serem sinônimas, apontam para algo que é real para quem crê mas não se reduz a uma categoria analítica.
} 
respostas foram desconsideradas na pesquisa. Não participaram estudantes de PósGraduação. 3

O questionário tinha como primeira finalidade avaliar comportamentos e opiniões dos estudantes sobre sua vida acadêmica. Entre os vários temas abordados em suas 253 perguntas, estão 53 referentes à religião. São as respostas a estas perguntas a fonte primária das informações aqui analisadas. Este artigo representa um tratamento dos dados, com o propósito de levantar os grandes temas a serem posterirormente desenvolvidos de modo mais elaborado.

Por tratar-se de um texto que pretende antes suscitar do que responder a questões, seu estilo é pouco acadêmico embora siga rigorosamente a metodologia da pesquisa científica. Os resultados das análises são apresentados de forma corrida, dispensando possíveis correlações, com o mínimo de tabelas e percentuais arredondados em 0,25\% para mais ou para menos. Perde-se então a precisão matemática mas ganha-se em fluência na apresentação dos resultados 4 .

O ponto de partida desta análise são os dados do último censo (IBGE, 2010), que oferecem um panorama geral da distribuição dos grandes grupos de religião segundo a idade. Eles são valiosos para apontar a especificidade da amostra utilizada na pesquisa. Sabendo que 93,5\% dos entrevistados têm entre 18 e 39 anos de idade, é possível comparar essa amostra aos dados gerais da população brasileira da mesma faixa etária. Temos então o seguinte quadro:

\footnotetext{
${ }^{3}$ Pesquisa realizada com apoio do CNPQ intitulada "Geração universitária: perfil atual. Um estudo de caso" (2012-2014). Pesquisadores responsáveis: Prof. Dr. Pedro Assis Ribeiro de Oliveira, Prof. Dr. Paulo Agostinho Nogueira Baptista e Prof. Dr. Roberlei Panasiewicz. Aprovada pelo CEP da PUC Minas, parecer 350.763.

${ }^{4}$ Por essa razão nem todas as tabelas fecham exatamente em $100 \%$.
} 
Tabela 1 - Religião declarada em \%

\begin{tabular}{|c|c|c|}
\hline Religião declarada & $\begin{array}{c}\text { Brasil } \\
\text { IBGE 2010 }\end{array}$ & $\begin{array}{c}\text { Religião atual: } \\
\text { universitários } \\
\text { PUC Minas 2013 }\end{array}$ \\
\hline Católicos & 64,5 & 55 \\
\hline Evangélicos & 22 & 17,5 \\
\hline Sem religião & 8 & 7,5 \\
\hline Ateus & & 5,5 \\
\hline Visão agnóstica & & 1 \\
\hline Espíritas & 2 & 6,5 \\
\hline Outras religiões & 5 & 6 \\
\hline Múltipla religiosidade & & 0,5 \\
\hline
\end{tabular}

Fontes: Dados da Pesquisa, Questão n. 101; IBGE, 2010

Ressalta imediatamente a menor presença de católicos e evangélicos na universidade do que na população total de mesma faixa etária. Por outro lado, é bem maior o percentual de jovens sem religião, ateus ou agnósticos, bem como os espíritas e de outras religiões. Esse fato serve de alerta para a especificidade dos dados de pesquisa a serem aqui examinados. Quem estuda juventude insiste que se deve falar no plural, pois cada setor da juventude tem particularidades especiais. (RODRIGUES, 2010, p. 225).

Focando o olhar sobre esta juventude universitária, vamos aqui retirar da pesquisa informações sobre o sentido da religião em suas vidas. Apresentaremos a análise dos dados em dois momentos. No primeiro momento, buscaremos dar uma visão global da religião vivida pela juventude universitária, sem distinguir suas adesões institucionais. Depois um estudo comparativo sobre católicos e evangélicos abrirá pistas para explicar como eles lidam com a religião no ambiente universitário. 


\section{Caracterização religiosa dos jovens universitários}

Um olhar pela sociedade brasileira atual chama a atenção a presença da religião na vida das pessoas e da sociedade. 5 Há enorme quantidade de templos espalhados pelas cidades, há forte atuação na mídia eletrônica, há crescente turismo religioso e, sobretudo, a presença do mercado em torno desses bens simbólicos. Nas sociedades tradicionais, a religião tinha função clara e lugar garantido. Nas sociedades atuais isso permanece? A religião recebida na infância é a que permanece na adolescência, na juventude e na vida adulta? Quais religiões são mais procuradas? Focando o olhar sobre a juventude universitária atual, o que é possível dizer sobre a presença da religião em suas vidas?

Ao apresentarmos os dados da pesquisa, procuraremos responder a essas questões. Para tanto, desenvolveremos o seguinte percurso: afiliação religiosa; ciclo da religião na vida dos jovens; educação e participação religiosa; aquisição de conhecimentos e avaliação do religioso; compreensão da diversidade religiosa e, por fim, a influência na vida pessoal e profissional.

\subsection{Afiliação religiosa}

Vimos na tabela 1 a distribuição do conjunto de estudantes segundo a religião declarada. É interessante notar que ao serem perguntados se tinham ou não religião ou religiosidade (questão $n^{0}$ 77) responderam afirmativamente 89,5\% e negativamente 10,5\%. Entretanto, temos 14\% que se declaram "sem religião", “ateus” e “de visão agnóstica”. Isso aponta para uma visão mais larga de religião ou religiosidade entre quem não se afilia a uma denominação religiosa. Comparados aos dados de pesquisa semelhante realizada em 1990 na PUC Minas, resulta um

\footnotetext{
${ }^{5}$ Alguns conceitos merecem esclarecimento quando se trata de religião, religiosidade e espiritualidade. Religiosidade, fé e religião são experiências dinâmicas das sociedades humanas. Podem ocorrem de forma articulada ou separadamente. "A religiosidade diz respeito à abertura existencial que o ser humano tem em relação ao Mistério transcendente, que o inunda, perpassa e traspassa [...] pode acontecer através da experiência religiosa ou da experiência de Deus [...] A experiência de fé indica a disposição interior do ser humano em dialogar e acolher ou não o Mistério transcendente. Ocorre na tradição religiosa ou fora dela. 0 processo de institucionalização da religiosidade denomina-se religião. Por ela, os seres humanos canalizam sua busca de valores transcendentais e criam símbolos, rituais, doutrinas, tradições e tornam imanentes e mais acessíveis tais realidades. Elas têm poder de manutenção de estruturas sociais, força de organização e mobilização em vista de transformações e mudanças de conjunturas sociopolíticas." (PANASIEWICZ, 2013, p. 608609).
} 
significativo aumento na percentagem dos jovens respondentes (263 numa amostra de 382) que se declaram religiosos, pois 69\% disseram ter religião e 31\% (119 estudantes) disseram não ter, incluindo os ateus $(113+6=119)$. (BAPTISTA, 2013).

Especificando os dados da pesquisa atual temos, em relação à Igreja Católica, junção da Católica Romana (53,5\%) e da Católica Ortodoxa (1,5\%), totalizando 55\%. Em relação aos evangélicos, podemos dizer que há os protestantes históricos (Presbiteriana, Luterana e Metodista) com 4\%; Batistas com 8,5\% e Pentecostais (Quadrangular, Assembleia de Deus, Congregação Cristã, Maranata, Igreja Universal do Reino de Deus, Deus é Amor) com 5,5\%. Aqui destaca-se a Igreja Batista. Entretanto, a pesquisa não diferenciou Batistas "tradicionais" de Batistas "renovados".

Os sem-religião aparecem na pesquisa com 7,5\%, ocupando o terceiro lugar na escolha dos respondentes. ${ }^{6}$ Há expressão significativas dos jovens que se declaram espíritas $(6,5 \%)$ e dos que se declaram ateus (5,5\%). Agrupando religiões que tiveram pequena porcentagem, temos "outras religiões" - Budismo, Messiânica, Adventista, Umbanda, Candomblé, Islamismo, Hinduísmo, Seicho-noie, Mórmons, Hare Krishna e outras - com a porcentagem de 6\%. O índice para as especificamente orientais é de o,6\%.

Esse quadro aponta para a grande fragmentação do religioso e uma pluralidade de opções religiosas crescente. Para Danièle Hervieu-Léger (2008, p. 42), esse fato demonstra "que a crença escapa totalmente ao controle das grandes igrejas e das instituições religiosas.” E, nas palavras de Claude Geffré (2004, p. 134), essa pluralidade de opções aponta para uma nova "consciência histórica de

\footnotetext{
6 "Sem religião" são designadas as pessoas que não tem pertença religiosa explícita, porém acreditam no misterioso ou transcendente e desenvolvem algum tipo de espiritualidade.
} 
um pluralismo religioso intransponível". ${ }^{7} \mathrm{O}$ plural perpassa todas as realidades do mundo contemporâneo, inclusive o religioso.

\subsection{Ciclo da religião na vida dos jovens}

A pesquisa procurou traçar o ciclo da religião na trajetória dos jovens desde a infância até o momento atual. Fica evidente a mobilidade e a transição do religioso. Observa-se também a perda constante de adeptos da religião católica. Entretanto, quais religiões estão em crescimento e quais estão perdendo adeptos? A tabela 2 elucida este ciclo. Houve 1195 jovens que declaram sua posição em relação à religião e 251 que deixaram de responder às questões referentes a esses dados.

Tabela 2 - Ciclo da religião

\begin{tabular}{|c|c|c|c|c|c|}
\hline Religiões & Infância & $\begin{array}{c}\text { Pré- } \\
\text { adolescência }\end{array}$ & Adolescência & Juventude & Atual \\
\hline Católica & $\mathbf{8 1}$ & $74 \downarrow$ & $63 \downarrow$ & $55,5 \downarrow$ & $\mathbf{5 5} \downarrow$ \\
\hline Evangélicos & $\mathbf{1 2}$ & $15,5 \uparrow$ & $17 \uparrow$ & $18,5 \uparrow$ & $\mathbf{1 7 , 5} \downarrow$ \\
\hline $\begin{array}{c}\text { Sem religião } \\
\text { (com fé) }\end{array}$ & $\mathbf{1 , 5}$ & $1,5 \uparrow$ & $4,5 \uparrow$ & $7 \uparrow$ & $7,5 \uparrow$ \\
\hline Espírita & $\mathbf{1 , 5}$ & $3,5 \uparrow$ & $5,5 \uparrow$ & $7 \uparrow$ & $\mathbf{6 , 5} \downarrow$ \\
\hline Ateu & $\mathbf{1}$ & $2 \uparrow$ & $5 \uparrow$ & $5 \uparrow$ & $\mathbf{5 , 5} \uparrow$ \\
\hline Agnóstico & $\mathbf{0}$ & $0 \downarrow$ & $1 \uparrow$ & $1 \uparrow$ & $\mathbf{1} \uparrow$ \\
\hline $\begin{array}{c}\text { Múltipla } \\
\text { religiosidade }\end{array}$ & $\mathbf{0}$ & 0 & $0,5 \uparrow$ & $0,5 \uparrow$ & $\mathbf{0 , 5} \uparrow$ \\
\hline
\end{tabular}

Fonte: Dados da Pesquisa, Questões n. 97, 98, 99, 100 e 101

\footnotetext{
7 M. Jayanth (2002, p. 164) apresenta uma distinção entre pluralidade e pluralismo. Pluralidade é a variável externa, indica quantitativamente as diferenças que existem em uma sociedade e a origem das diferenças como religião, língua, raça, casta e outras parecidas. O pluralismo é um coeficiente interno, refere-se a uma atitude específica que se desenvolve entre os grupos sociais em resposta ao fato da pluralidade.
} 
Destacado em negrito a afiliação religiosa que esses jovens declararam ter na infância e na atualidade. É evidente que a queda percentual de católicos (de 81\% na infância para 55\% hoje), corresponde ao crescimento das demais. Veremos mais adiante, contudo, que esse movimento pode dar-se também em sentido inverso, embora muito mais raro. Se compararmos somente a opção religiosa da época da juventude com a atual a queda acontece no catolicismo, nos evangélicos e no espiritismo. Nas demais expressões religiosas há crescimento. A religião Católica continua sendo a majoritária, apesar da perda constante de fiéis. Os evangélicos, mesmo havendo pequena perda entre a faixa da juventude e a atual, apresenta, ao longo do ciclo da vida, crescimento de 5,5\%. O grupo "sem religião" sinaliza crescimento (6\%), juntamente com o espiritismo (5\%) e ateísmo (4,5\%). Por fim, há presença mais tímida dos agnósticos e dos que se consideram com múltipla pertença. Percebe-se acentuada mobilidade religiosa, acenando para crescente fragmentação do religioso. Isso responde a um movimento da modernidade de criticar os sistemas religiosos e, ao mesmo tempo, de suscitá-los. Nas palavras de Hervieu-Léger (2008, p. 41),

a secularização não é, acima de tudo, a perda da religião no mundo moderno. É o conjunto dos processos de reconfiguração das crenças que se produzem em uma sociedade onde o motor é a não satisfação das expectativas que ela suscita, e onde a condição cotidiana é a incerteza ligada à busca interminável de meios de satisfazê-las.

Não permitir que se realizem as expectativas provoca estado de alerta em toda a sociedade e suscita o desejo por realizar. Assim, o trânsito religioso vira uma constante, pois a insatisfação e a incerteza são crescentes e a busca pela satisfação e pela segurança sustenta esse movimento. Em outras palavras, toda religião busca responder aos questionamentos existenciais que perpassa o imaginário de todo ser humano, sobretudo no que se refere a relação entre vida e morte. Como essas questões são constantes na vida humana, gera situação de insegurança e busca por satisfação. $\mathrm{O}$ trânsito religioso também pode ser compreendido nesse movimento. 


\subsection{A educação e a participação religiosa}

A respeito da continuidade do religioso, foi perguntado (questão $\mathrm{n}^{0}$ 105) se eles dariam educação religiosa a seus filhos. A maioria, 83,5\%, afirma que dará educação religiosa contra $7 \%$ que preferem não dar esse tipo de educação aos seus filhos. Há, ainda, 10\% que ainda não definiram se darão ou não formação religiosa para seus filhos. Esses números sinalizam a grande importância que o religioso ocupa na vida das pessoas. Mesmo ocorrendo mobilidade e trânsito, o desenvolvimento da religiosidade é valorizado pela maioria dos jovens. A transmissão numa sociedade tradicional e estática simbolizava a perpetuação de um tipo de sociedade. Entretanto, numa sociedade em que a crise e as mudanças fazem parte do cotidiano, a transmissão também ganha nova característica. Filhos de pais seguidores de uma religião também terão essa instituição como referência? E quando os pais seguem tradições religiosas distintas, em qual educarão seus filhos? As respostas a essas perguntas provavelmente sinalizam características novas de uma sociedade em movimento e de reelaborações constantes. Outro questionamento que emerge nesse contexto é em relação à memória das próprias tradições religiosas, quem as guardará se o trânsito e o movimento se tornam constantes?

A pesquisa procurou saber (questão $n^{0}$ 129) com que frequência os respondentes iam às cerimônias religiosas. Agrupando as respostas, temos as seguintes referências: $32 \%$ participam regularmente (todo dia ou ao menos três vezes por semana); 25\% frequentam às vezes (vão às cerimônias de uma a três vezes por mês); 26,5\% frequentam raramente, (somente em eventos sociais); e $5,5 \%$ não frequentam. Nessa pergunta específica, $11 \%$ disseram não ter religião. Temos, portanto, quase 60\% dos jovens respondentes dizendo frequentar cerimônias religiosas pelo menos uma vez por mês.

Sobre fazer as preces e as orações fora dos lugares sagrados e de culto (questão $n^{0}$ 130), a resposta indica que mais da metade (53,5\%) fazem preces e orações todos os dias em particular; $11 \%$ fazem de duas a três vezes por semana; 
7,5\% uma vez por semana. Somando estes índices, temos que $72 \%$ dos jovens fazem preces e orações regularmente fora dos lugares sagrados e de culto. Ainda temos 5,5\% que fazem, pelo menos, uma vez por mês e 13,5\% disseram fazer muito raramente essas orações. Por fim, temos $9 \%$ que nunca fazem preces e orações fora dos lugares sagrados e de culto. Interessante notar que, na questão anterior, 11\% disseram não ter religião e nessa temos somente $9 \%$ que não fazem preces e orações fora dos lugares sagrados e de culto. Provavelmente a diferença de 2,5\% dos respondentes dizem não ter religião, mas desenvolvem sua espiritualidade, pois fazem suas orações no cotidiano da vida.

A presença da religião, expressa sobretudo na participação de suas cerimônias e na vida de oração, torna a tese de Peter Berger ainda vigente. Para ele, "a religião é o empreendimento humano pelo qual se estabelece um cosmo sagrado" e, por isso mesmo, com ela se consegue construir um "escudo contra o terror" da falta de sentido. (BERGER, 1985, p. 38). Esse é um dos grandes entraves do sujeito contemporâneo: a crise de sentido. Se, por um lado, constata-se uma crise das grandes instituições religiosas pela perda de adeptos, por outro lado, percebe-se o crescimento e fortalecimento de outras espiritualidades (não tradicionais) e também dos sem religião. Temos $32 \%$ dos respondentes que frequentam os lugares de culto todos os dias ou de uma a três vezes por semana e temos 53,5\% que fazem as preces e as orações fora dos lugares sagrados e de culto todos os dias. Isso demonstra a presença do religioso no dia a dia desses jovens. Mesmo em meio à velocidade que gira o mundo contemporâneo devido, sobretudo, aos meios de comunicação, a maioria encontra tempo e espaço para cultivar sua vida de oração. Mesmo não sabendo que tipo de espiritualidade é desenvolvida pelos respondentes, porém, constata-se a sua presença.

\subsection{Aquisição de conhecimentos religiosos e avaliação do religioso}

A pesquisa procurou saber como esses jovens adquirem ou fazem a atualização dos conhecimentos religiosos. Cada pergunta foi avaliada 
separadamente. A maioria, 72\%, disse receber através da participação em cultos e rituais (questão n⿳ 83); em segundo lugar, 59,5\%, adquire através de leituras dos livros sagrados ou religiosos (questão $\mathrm{n}^{\mathrm{o}}$ 82); em terceiro lugar, 57,5\%, pela orientação dos líderes religiosos (questão $n^{\circ}$ 87); pelas redes sociais e internet, $51 \%$ (questão $n^{\circ}$ 86); via meios de comunicação, rádio e TV (questão nº 85), e através de retiros, encontros e missões (questão $n^{0}$ 84) ficou empatado com $45 \%$ das preferências. Essas respostas assinalam a grande responsabilidade dos líderes religiosos ante os seus adeptos, pois a maioria recebe os ensinamentos através da participação em cultos e rituais e/ou diretamente das suas orientações. As religiões, como hipóstases sociais, podem auxiliar na formação de jovens protagonistas de sua história e da construção de uma sociedade cidadã ou podem propiciar atitudes de subserviência. Interessante sinalizar que os meios de comunicação social, redes sociais e internet não ocupam lugar de destaque na aquisição e atualização dos conhecimentos religiosos.

Avaliando a própria religiosidade e seu seguimento (questões $n^{0} 78$ e 81), a maioria avalia bem a religiosidade, dando nota total, mas não em relação ao seguimento. Aliás, são mais críticos ao avaliar o próprio seguimento. Tendo como referência a nota 10, a maioria atribuiu nota 7 a 8 a si próprio e nota 9 a 10 às doutrinas e aos ensinamentos morais que recebem de suas instituições. Outro ponto que convém salientar sobre esses jovens diz respeito a sua compreensão do que seja ensinamento doutrinal e ensinamento moral, pois não fizeram distinção e os avaliam de forma idêntica (questões $n^{0} 79$ e 80). O ensinamento doutrinal diz respeito ao conjunto (sistemático) das verdades propostas por uma religião, tendo como referência as narrativas sagradas. São mais permanentes. O ensinamento moral aponta para os costumes que cada religião estabelece para a vida dos adeptos. Esses são dinâmicos e mudam com o passar dos tempos. A tabela a seguir mostra as respostas de 1067 jovens. 


\section{Tabela 3 - Avaliação da religiosidade própria e ensinamentos da instituição em \%}

\begin{tabular}{|c|c|c|c|c|}
\hline & $\begin{array}{c}\text { Própria } \\
\text { religiosidade }\end{array}$ & $\begin{array}{c}\text { Próprio } \\
\text { Seguimento }\end{array}$ & Doutrinas & $\begin{array}{c}\text { Ensinamentos } \\
\text { Morais }\end{array}$ \\
\hline $\begin{array}{l}\text { Nota } \\
\text { 9 a 10 }\end{array}$ & 39 & 24 & 39 & 39 \\
\hline $\begin{array}{l}\text { Nota } \\
7 \text { a } 8\end{array}$ & 32,5 & 37,5 & 32,5 & 32,5 \\
\hline $\begin{array}{l}\text { Nota } \\
5 \text { a } 6\end{array}$ & 20,5 & 25 & 20,5 & 20,5 \\
\hline $\begin{array}{l}\text { Nota } \\
\text { a } 4\end{array}$ & 5 & 8,5 & 5 & 5 \\
\hline $\begin{array}{l}\text { Nota } \\
\text { O a } 2\end{array}$ & 3,5 & 5,5 & 3,5 & 3,5 \\
\hline
\end{tabular}

Fonte: Dados da Pesquisa, Questões n. 78, 79, 80 e 81

Destaque se dá à avaliação da própria religiosidade, pois 39\% dos estudantes se autoavaliam em 9/10. Considerando essa mesma nota e em relação o próprio seguimento o índice cai para 24\%. Há uma diferença de $15 \%$. Isso pode indicar que são mais críticos em relação a si mesmos do que em relação à instituição ou sinaliza que as pessoas têm abertura ante o misterioso ou transcendente, mas não encontram respostas nas instituições religiosas que aí se encontram, por isso cai o índice em relação ao seguimento. Em outras palavras, demostram ter fé e querer desenvolver a espiritualidade, mas não encontram o que procuram nas instituições que aí estão, por isso, não seguem.

\subsection{Diversidade religiosa e diálogo}

A pesquisa procurou saber como esses jovens se posicionam ante a diversidade religiosa, a postura intransigente e se concordam com práticas dialógicas entre tradições religiosas diferentes. As respostas foram variadas, expressando pluralidade também na maneira de compreender a realidade. Em relação a conviver com a diversidade religiosa (questão $n^{0} 106$ ), $92 \%$ afirmam não ter problemas com a diferença religiosa. Entretanto, ao responder sobre se toleram ou não religiões que invocam espíritos (questão ${ }^{0}{ }^{123}$ ) o índice caiu para 74,5\%. 
Parece haver uma admissão para o convívio social, mas não aceitação do diferente em suas especificidades. Um alto índice, 75\%, aceita dizer que as diferentes religiões expressam diferentes maneiras de Deus se revelar (questão $\mathrm{n}^{0} 113$ ), contra 25\% que não concordam. Entretanto, somente 44,5\% aceitam que "não há religião falsa. Todas as religiões são verdadeiras" (questão $n^{0} 121$ ). Isso pode expressar que consideram haver graus distintos para avaliar a veracidade das expressões religiosas ou pode apontar para compreensões mais exclusivistas da prática religiosa. Nesse caso, defende-se uma prática sobre a outra, pois se considera que uma seja "mais verdadeira" do que a outra.

Índice parecido aos que não concordam que Deus possa se expressar de várias maneiras são os $28 \%$ que assumem postura intransigente e recusam a hermenêutica na maneira de ler o Livro Sagrado (questão $n^{0}$ 115). Essas duas perspectivas assinalam para um fechamento nesse grupo de respondentes, pois indiretamente defendem que a verdade absoluta encontra-se em sua religião (Deus não se expressa de várias maneiras). Isso carrega a noção de que só o missionário dessa tradição leva o Espírito de Deus às outras tradições e culturas. E mais, se fechar à hermenêutica significa aceitar somente como válida a interpretação subjetiva da narrativa sagrada.

A grande maioria de $85,5 \%$ concorda que deve haver o diálogo interreligioso (questão $\mathrm{n}^{0}$ 118), pois ajuda no desenvolvimento e amadurecimento da fé; 14,5\%, porém não percebem que possa haver enriquecimento com essa prática. Ao tornar-se cada vez mais plural e mais conectado pelas redes de comunicação, o mundo contemporâneo vai acentuando práticas dialogais. Isso aponta para a disposição que a maioria tem para a construção de sociedades democráticas e participativas. Educar para a tolerância ante o diferente ajuda a minimizar práticas intransigentes e a construir a cultura da paz. Novamente os líderes religiosos são convocados a prestar atenção nesses índices. A tabela a seguir apresenta a síntese dessas respostas dadas por 1195 pessoas. 
Tabela 4 - Diversidade religiosa e diálogo em \%

\begin{tabular}{|c|c|c|}
\hline Perguntas & Sim & Não \\
\hline Convive bem com a diversidade religiosa & 92 & 3,5 \\
\hline O mundo seria melhor sem religião & 12 & 69,5 \\
\hline Diferentes religiões expressam diferentes revelações & 75 & 25 \\
\hline Tolerância com religiões que invocam espíritos & 74,5 & 25,5 \\
\hline Todas as religiões são verdadeiras & 44,5 & 55,5 \\
\hline O Livro Sagrado deve ser lido “ao pé da letra” & 27,5 & 72,5 \\
\hline O diálogo entre as religiões ajuda a aumentar a fé & 85,5 & 14,5 \\
\hline
\end{tabular}

Fonte: Dados da Pesquisa, Questões n. 106 e 107, 113, 115, 118, 121 e 123

\subsection{Religião e vida pessoal e profissional}

Muito se fala sobre a ajuda que as religiões proporcionam à vida das pessoas, seja pessoal (questão $n^{0}$ 119) seja profissional (questão $n^{0} 128$ ). A pesquisa procurou saber o que os jovens universitários pensam a esse respeito. A grande maioria, 91,5\%, considera que as religiões ajudam a enfrentar os problemas e os desafios da vida. E 86,5\% consideram que na religião há espaço para ampliar a qualidade dos relacionamentos, inclusive entre gerações (questão $n^{0}$ 127). Seguindo nessa direção, $78 \%$ consideram que a oração é um instrumento poderoso para conseguir os objetivos na vida e a ajudar na cura das doenças (questão $\mathrm{n}^{\mathrm{o}}$ 125). E, por fim, $76,5 \%$ desses jovens pensam que a religião ajuda na vida profissional. Por esses índices, contata-se que a religião e a oração não só estão presentes como são importantes na vida dos respondentes. Também foi perguntado sobre a presença de forças demoníacas e do mal como forma de explicar os problemas da vida humana (questão $n^{0} 124$ ). As respostas sinalizam uma visão crítica dos jovens, pois $77 \%$ discordam que haja esse tipo de influência. 
As respostas indicam que a religião e a prática da oração ajudam a dar plausibilidade à vida das pessoas. ${ }^{8} \mathrm{Na}$ percepção de Berger (1985, p. 39), “o sagrado é apreendido como algo que 'salta para fora' das rotinas normais do dia a dia" e, estes "saltos”, ajudam o ser humano a colocar "a sua vida em ordem, dotada de significado”. Percebemos que a pluralidade de opções religiosas não enfraquece o sentido que a religião dá às pessoas. Pelo contrário, possibilita nova maneira de ver e interpretar a presença do sagrado em suas vidas. A pluralidade de interpretações aponta para a riqueza do mistério que transcende a realidade e indica a busca tateante por um sentido maior.

\section{Universitários católicos e evangélicos: análise comparativa}

Tendo como pano de fundo a experiência religiosa dos estudantes, cabe perguntar como esse pendor adquire concretude em sua vida, uma vez que a fé pode ser confinada à dimensão subjetiva, não à religião. Como bem define a obra clássica de E. Durkheim (1960, p. 60) a religião requer alguma forma de adesão à comunidade que professa a mesma fé e, no limite, uma adesão à Igreja como instituição social. Este é o tema central dos próximos tópicos, que trazem dados sobre as relações entre os fiéis e a instituição religiosa a que pertencem. Ao fazê-lo reduzimos o campo de observação aos dois grandes conjuntos cristãos: católicos e evangélicos.

\subsection{Perseverança e trânsito religioso}

Embora a tabela $n^{\circ} 2$ deixe clara a desafeição ao catolicismo no decorrer da vida, convém esclarecer que ocorre também o processo inverso. A análise das questões que compõem a tabela mostra que 22 estudantes (3,5\% do total) se tornaram católicos em algum momento entre a infância e a juventude, pois em sua trajetória de vida consta outra afiliação religiosa: pentecostais (7), espíritas (7), batistas (3), protestantes (2), sem-religião (2) e outra (1). Cabe observar que o

\footnotetext{
${ }^{8}$ Isso pode indicar por que há maior procura pela religião nos jovens de hoje do que retratou a pesquisa de 1990. Para um estudo comparado, haveria necessidade de analisar a conjuntura social, política e econômica dos dois momentos, mas não cabe a esse estudo.
} 
mesmo não se dá com o catolicismo de rito ortodoxo, que mantem a mesma quantidade de adeptos ao longo do tempo. A realidade é inteiramente outra no caso dos evangélicos, onde o percentual de mudanças de religião chega a 46\%: 87 pessoas tinham sido católicas, 9 sem religião e 1 espírita.

Deve-se notar que mudança de religião não significa pouca consideração por ela. Dois dados chamam a atenção por revelarem o apreço dos estudantes por sua religião. O primeiro vem da questão no 105: $94 \%$ dos católicos e 90\% dos evangélicos têm o propósito de transmiti-la a seus descendentes. O outro é dado pela questão $\mathrm{n}^{\mathrm{o}} 107$, onde se pede a opinião sobre se o mundo seria melhor sem religião: $76,5 \%$ dos católicos e 77,5\% dos evangélicos responderam à negativamente, enquanto somente 9\% (o mesmo para católicos e evangélicos) considera a religião prejudicial ao mundo e o restante não sabe avaliar. Esse apreço pela religião é compatível com a concentração de respostas afirmativas quanto à avaliação positiva da religião vivida na infância: 94\% dos católicos e 79,5\% dos evangélicos, como aponta a questão n⿳0 104. É interessante observar que mesmo no conjunto de evangélicos onde ocorreram mudanças de religião, são poucas as pessoas que consideram negativa sua experiência religiosa durante a infância.

Tendo esse quadro como referência, vejamos então algumas práticas desses estudantes procurando detectar em que medida elas contribuem para sua perseverança religiosa.

\subsection{Práticas religiosas e ligação com a instituição religiosa}

Embora a prudência leve a suspeitar da quantidade de respostas sobre frequência a atos de culto, por ser ela quase sempre exagerada por quem dá a informação, a observação dos dados comparativos é reveladora: 
Tabela 5 - Frequência à igreja em \%

\begin{tabular}{|c|c|c|}
\hline Frequência à igreja & Católicos & Evangélicos \\
\hline$>1$ / semana & 6,5 & 28 \\
\hline 1 / semana & 24,5 & 33,5 \\
\hline$>1$ mês & 15,5 & 10,5 \\
\hline 1 / mês & 17,5 & 10,5 \\
\hline Raramente & 36 & 17,5 \\
\hline $\mathbf{N}^{\mathbf{0}}$ Total de respondentes & $\mathbf{6 5 9}$ & $\mathbf{2 1 1}$ \\
\hline
\end{tabular}

Fonte: Dados da Pesquisa, Questão n. 129

Tendo em vista que as Igrejas católicas e evangélicas oferecem a seus fiéis mais de uma oportunidade de cerimônias religiosas nas igrejas a cada semana, é nítida a ausência de um número significativo de católicos $(53,5 \%)$ e mesmo de evangélicos (28\%). As proporções se invertem quando se vê a presença ao menos semanal na igreja: $31 \%$ dos católicos e 61,5\% de evangélicos. Esses dados são compatíveis com os dados de outras pesquisas de prática religiosa.

Tabela 6 - Práticas fora da igreja em \%

\begin{tabular}{|c|c|c|}
\hline Práticas fora da igreja & Católicos & Evangélicos \\
\hline$>1$ / semana & 71 & 78,5 \\
\hline 1 / semana & 8 & 7,5 \\
\hline 1 ou > 1 / mês & 6,5 & 2,5 \\
\hline Raramente / nunca & 14,5 & 11,5 \\
\hline $\mathbf{N}^{\text {o }}$ Total de respondentes & $\mathbf{6 5 9}$ & $\mathbf{2 1 1}$ \\
\hline
\end{tabular}

Fonte: Dados da Pesquisa, Questão n. 130

Os resultados da pesquisa suscitam maior reflexão ao indicar altos percentuais de ausência de prática religiosa também no âmbito privado. Posto que todas as pessoas aqui consideradas declararam ter religião - católica ou evangélica - é surpreendente que não se ocupem com ela ao menos um dia por mês, em 
qualquer espaço à sua escolha além dos templos. $\mathrm{O}$ esperado de quem se declara religioso é que pelo menos uma vez por semana se dedique a alguma prática de oração ou prece - como faz a grande maioria dos evangélicos e católicos.

Essa constatação leva a colocar em questão a formação religiosa dos estudantes.

Onde ambiente universitário oferece espaço para convivência e debates fora da sala de aulas - como ocorre na PUC-Minas - não é raro que a religião seja questionada por argumentos científicos e filosóficos que suspeitam de sua fundamentação racional. Esse confronto de ideias pode abalar a fidelidade religiosa, que precisa apoiar-se em processos de formação que garantam a perseverança dos adeptos. As Igrejas normalmente oferecem diversos meios de atualização da formação religiosa. As tabelas seguintes mostram seu alcance entre os estudantes entrevistados.

Tabela 7 - Meios de atualização religiosa em \%

\begin{tabular}{|l|c|c|}
\hline \multicolumn{1}{|c|}{ Meio utilizado } & Católicos & Evangélicos \\
\hline Culto & 71 & 93 \\
\hline Encontros & 42 & 70 \\
\hline TV ou rádio & 46 & 40,5 \\
\hline Redes sociais / internet & 48 & 63,5 \\
\hline Livros sagrados & 49 & 84 \\
\hline Orientação pessoal & 43,5 & 80 \\
\hline No Total de respondentes & $\mathbf{6 5 4}$ & $\mathbf{1 9 7}$ \\
\hline
\end{tabular}

Fonte: Dados da Pesquisa, Questões n. 82, 83, 84, 85, 86 e 87

É nítida a diferença entre evangélicos e católicos quanto ao que eles percebem ser suas fontes de atualização de formação religiosa. Com exceção da TV e rádio, todos os demais meios de atualização religiosa são mais utilizados por evangélicos, sobressaindo o próprio momento de culto e o estudo da Bíblia (que 
também para os católicos são os dois meios mais frequentes, embora em bem menores proporções).

Esse subconjunto de dados referentes à prática e à formação religiosa indicam maior adesão às práticas e formação oferecida por sua Igreja entre os estudantes evangélicos do que entre os católicos. Estes são dados congruentes com outras pesquisas sobre religião no Brasil: a pertença religiosa é mais forte entre evangélicos do que entre católicos.

\subsection{Adesão à instituição religiosa}

Diferentemente da fé, que pode reduzir-se à dimensão subjetiva, a religião requer adesão institucional. As instituições religiosas podem apresentar variadas formas, inclusive no interior de uma mesma confissão religiosa (basta pensar, por exemplo, de uma diocese para outra, ou mesmo em diferentes comunidades da mesma paróquia), assim como o grau de adesão do fiel a essas instituições. As tabelas seguintes oferecem dados para comparar diferentes formas de adesão institucional e seu grau, sempre tomando o conjunto dos católicos e dos evangélicos.

Para dimensionar a diferença qualitativa entre a total e a simples concordância, foi atribuído peso 2 às respostas que dizem "concordo totalmente". Consequentemente, foi atribuído peso -2 às respostas que dizem "discordo totalmente": a média dos resultados multiplicada por 100 dá o índice de concordância / discordância com aquele atributo. Assim, a tabela seguinte reúne numa coluna as respostas positivas ("concordo e concordo totalmente") e na outras as respostas negativas ("discordo e discordo totalmente”), descartando as respostas de quem assinalou não saber avaliar.

\subsubsection{Imagem do líder religioso}

Dado que a instituição se visibiliza por meio de agentes religiosos, serão estes tomados como indicadores da adesão institucional. Embora a imagem do 
líder religioso não possa ser identificada com a imagem da instituição, com certeza uma imagem favorável indica apreço à instituição. Note-se, porém, a ambiguidade da pergunta. Por se tratar de um único questionário aplicado ao conjunto de estudantes da PUC Minas, não era possível especificar de qual "líder religioso" se tratava. Um católico pode ter em mente o papa, o bispo de sua arquidiocese ou região pastoral, o vigário paroquial ou a liderança de sua comunidade. $\mathrm{O}$ evangélico pode referir-se ao pastor, ao bispo ou a alguma liderança nacional de sua Igreja. Apesar disso, o indicador revela-se significativo, como será mostrado a seguir.

\section{Tabela 8 - Liderança religiosa}

\begin{tabular}{|l|c|c|c|c|}
\hline & \multicolumn{2}{|c|}{ Católicos } & \multicolumn{2}{c|}{ Evangélicos } \\
\hline \multicolumn{1}{|c|}{ Atributos do líder } & positivos & negativos & positivos & negativos \\
\hline Bom conhecimento & 96 & 9 & 148 & 5 \\
\hline Bom relacionamento & 96 & 8 & 138 & 7 \\
\hline Espiritualidade / sabedoria & 101 & 6 & 146 & 3 \\
\hline Bom celebrante & 94 & 13 & 140 & 5 \\
\hline Preocupação com valores & 91 & 13 & 140 & 4 \\
\hline Coerência ética & 77 & 16 & 119 & 12 \\
\hline Liderança democrática & 83 & 14 & 114 & 17 \\
\hline Relação com dinheiro & 65 & 26 & 98 & 34 \\
\hline Relação com o social & 87 & 12 & 104 & 21 \\
\hline \multicolumn{1}{|c|}{ Pontuação total } & $\mathbf{7 9 0}$ & $\mathbf{1 1 7}$ & $\mathbf{1 . 1 4 7}$ & $\mathbf{1 0 8}$ \\
\hline Total de respondentes & $\mathbf{6 4 9}$ & & $\mathbf{1 9 7}$ & \\
\hline
\end{tabular}

Fonte: Dados da Pesquisa, Questões n. 88, 89, 90, 91, 92, 93, 94, 95 e 96

A tabela deixa claro que a imagem do líder religioso é amplamente positiva, na proporção de quase 7 para 1 entre o conjunto de estudantes católicos, e mais de 10 para 1 entre o conjunto de evangélicos. Essa imagem é mais favorável no que se refere a atributos propriamente religiosos (conhecimento, bom relacionamento, espiritualidade / sabedoria, capacidade celebrativa e preocupação com valores). 
Nota-se uma diferença entre católicos e evangélicos no que se refere aos dois últimos aspectos, para os quais os católicos têm avaliação um pouco menos favorável. Já nos quesitos de comportamento do líder religioso (coerência ética, democracia, relação com o dinheiro, e relação com a sociedade, ecologia e política) ambos grupos são bem mais críticos de seu líder.

\subsubsection{Opiniões sobre temas religiosos e comportamentais}

Outro indicador de adesão institucional é a conformidade com a teologia da Igreja. Embora esta possa receber diferentes interpretações, é de se esperar certo grau de concordância com a doutrina oficial como sinal de adesão do fiel à instituição que representa sua confissão religiosa. Surge aqui a dificuldade de saber qual é a doutrina de referência, especialmente no caso dos evangélicos, pois ali foram agregadas confissões bem diferentes entre si quanto à doutrina e às normas morais.

Também nesta questão a formulação das perguntas deixa a possibilidade de ambivalência de sentidos, o que influencia a resposta. Por isso não é seguro que a resposta assinalada no questionário expresse exatamente a opinião do entrevistado. Feita essa ressalva, examinaremos duas tabelas complementares: a primeira com proposições onde seria esperada maior concordância, e outra cujos quesitos deveriam suscitar discordância. 
Tabela 9 - Concordância com temas teológicos

\begin{tabular}{|c|c|c|c|c|}
\hline & \multicolumn{2}{|c|}{ Católicos } & \multicolumn{2}{c|}{ Evangélicos } \\
\hline Crenças & concordância & discordância & concordância & discordância \\
\hline $\begin{array}{c}\text { Leitura literal do } \\
\text { Livro sagrado }\end{array}$ & 31 & 97 & 85 & 55 \\
\hline $\begin{array}{c}\text { Demônios explicam } \\
\text { o mal }\end{array}$ & 24 & 106 & 52 & 74 \\
\hline $\begin{array}{c}\text { Oração: instrumento } \\
\text { poderoso }\end{array}$ & 120 & 18 & 143 & 18 \\
\hline Pontuação total & $\mathbf{1 7 5}$ & $\mathbf{2 2 1}$ & $\mathbf{2 8 0}$ & $\mathbf{1 4 7}$ \\
\hline $\begin{array}{c}\text { Total de } \\
\text { respondentes }\end{array}$ & $\mathbf{6 5 9}$ & & $\mathbf{2 1 1}$ & \\
\hline
\end{tabular}

Fonte: Dados da pesquisa, Questões n.115,124 e 125

Tabela 10 - Discordância com temas teológicos

\begin{tabular}{|c|c|c|c|c|}
\hline & \multicolumn{2}{|c|}{ Católicos } & \multicolumn{2}{c|}{ Evangélicos } \\
\hline Crenças & concordância & discordância & concordância & discordância \\
\hline $\begin{array}{c}\text { Deus: conceito } \\
\text { subjetivo }\end{array}$ & 92 & 40 & 41 & 96 \\
\hline Diferentes revelações & 116 & 23 & 83 & 55 \\
\hline Não há religião falsa & 64 & 63 & 28 & 117 \\
\hline Reencarnação e carma & 44 & 84 & 12 & 143 \\
\hline Não invocar espíritos & 34 & 95 & 58 & 75 \\
\hline Pontuação total & $\mathbf{3 0 6}$ & $\mathbf{3 0 5}$ & $\mathbf{2 2 2}$ & $\mathbf{4 8 6}$ \\
\hline $\begin{array}{c}\text { Total de } \\
\text { informantes }\end{array}$ & $\mathbf{6 5 9}$ & & $\mathbf{2 1 1}$ & \\
\hline
\end{tabular}

Fonte: Dados da pesquisa, Questões n. 116, 113, 121, 120, 123

Mesmo levando em conta os reparos feitos acima sobre as deficiências dos indicadores usados, fica evidente a diferença no grau de adesão às crenças institucionais de católicos e evangélicos. Onde seria esperada concordância, entre os católicos predomina a discordância que incide sobre dois temas (leitura literal da Bíblia e demônios), embora contrabalançada pela grande concordância no item 
sobre o poder da oração. Entre os evangélicos predomina largamente a concordância com as proposições institucionais, exceto no item referente à explicação do mal pela existência de demônios (proposta mais frequente nas igrejas pentecostais ou neopentecostais do que nas igrejas históricas). (Tabela 9).

A Tabela 10 apresenta, como num espelho, a mesma realidade: os católicos aceitam as propostas institucionais em grau bem menor do que os evangélicos. Onde seria esperada a discordância, como nas propostas de que "Deus é um conceito pessoal. Cada um tem o seu" e "as diferentes religiões mostram que Deus se revela de diferentes maneiras" há grande concordância. Note-se, contudo a rejeição da reencarnação e do carma como explicação das diferenças sociais e de problemas como doença e sofrimento. Já entre os evangélicos a discordância institucionalmente prescrita é muito forte, exceto na proposta das religiões como diferentes revelações de Deus.

\section{Tabela 11 - Disciplina eclesiástica e gênero}

\begin{tabular}{|l|c|c|c|c|}
\hline \multicolumn{1}{|c|}{ Temas } & \multicolumn{2}{c|}{ Católicos } & \multicolumn{2}{c|}{ Evangélicos } \\
\hline Castidade pré-matrimonial & concordância & discordância & concordância & discordância \\
\hline Homem: cabeça da família & 28 & 101 & 99 & 46 \\
\hline Proibição de camisinha & 16 & 104 & 88 & 48 \\
\hline Padre não deve casar-se & 61 & 133 & - & - \\
\hline Liderança masculina & 19 & 68 & - & - \\
\hline \multicolumn{1}{|c|}{ Pontuação total } & $\mathbf{1 5 2}$ & $\mathbf{5 3 7}$ & $\mathbf{1 8 7}$ & $\mathbf{9 4}$ \\
\hline Total de informantes & $\mathbf{6 5 9}$ & & $\mathbf{2 1 1}$ & \\
\hline
\end{tabular}

Fonte: Dados da pesquisa, Questões n. 110, 114, 111, 112 e 117

Essa Tabela 11 deve ser interpretada com bastante cautela, pois os ensinamentos de ordem sexual e de gênero não são os mesmos nas Igrejas católica e evangélicas. Por essa razão, foram desconsideradas as respostas dos evangélicos às três questões específicas à Igreja católica. Só podem ser comparadas as respostas referentes ao valor da castidade pré-matrimonial e ao homem como cabeça da 
família. E aí é evidente o contraste de posições: discordância de 3,5 para 1 entre os católicos e concordância de 2 para 1 entre os evangélicos. A proibição de casamento para os padres é o único item onde a rejeição é menos forte.

Essas três tabelas são congruentes entre si ao apontarem muito maior adesão institucional entre os evangélicos do que entre os católicos. Neste sentido, a pesquisa mostra que os católicos são mais liberais do que os evangélicos. No entanto, esta não é a autopercepção dos católicos, pois ao responderem a questão $\mathrm{n}^{\mathrm{o}} 122$ “os católicos são muito liberais e pouco exigentes em relação aos evangélicos" o índice de concordância não passou de 34, enquanto a discordância chegou a 85. Ou seja, de cada 5 católicos apenas 2 consideram os católicos liberais e pouco exigentes. Já a percepção dos evangélicos é diferente: o índice de concordância chega a 67 enquanto a discordância fica em 57.

A interpretação dos dados sobre a fraca adesão dos universitários católicos à instituição religiosa é corroborada pela questão 109 que pede para identificar sua forma de expressão religiosa. Nela se constata que 46,5\% se identificam apenas com "os costumes católicos tradicionais e os sacramentos”, 22,5\% tem seu "próprio jeito de ser católico", 6\% se reconhecem católicos "só de nome" e 3\% não se declaram católicos (esta é provavelmente o caso dos católicos ortodoxos, cujas respostas não foram discriminadas). Ou seja, quase 80\% dos estudantes revelam sua pequena ou quase nula adesão à instituição religiosa. Entre os que se identificam com uma linha interna à instituição religiosa, destacam-se os carismáticos com $15 \%$ do total de estudantes católicos. Identificam-se com a Teologia da Libertação, Comunidades de Base ou similares 3,5\%, enquanto 0,5\% se identificam com a linha conservadora que não aceita as mudanças introduzidas pelo Vaticano II. Note-se que $2 \%$ dizem ser integrados à comunidade paroquial e que $1,5 \%$ assinalaram outra forma de participação. 


\subsection{Uma visão de conjunto}

Esta análise do conjunto de estudantes da tradição cristã - católicos e evangélicos, de diferentes confissões - partiu da constatação de seu apreço pela religião mesmo num ambiente desfavorável à manutenção de crenças cristãs, como é o mundo universitário laico. Tal apreço, porém, não se traduz necessariamente em submissão do jovem às prescrições estabelecidas pela instituição religiosa com a qual se identifica. Isso foi demonstrado em várias tabelas, deixando sempre evidente a diferença entre católicos e evangélicos: em todos os itens pesquisados os católicos revelam estar mais afastados das práticas e orientações eclesiásticas do que os evangélicos.

Ao apresentar aqui os principais resultados desse estudo comparativo, não é seguida a ordem das tabelas, mas uma ordem que permita encaminhar uma resposta à questão colocada no início deste artigo: como a juventude universitária atual pratica o cristianismo?

Subjacente a essa pergunta está o profundo impacto da modernidade na religião. O tema tem sido tratado sob muitos aspectos: um deles é a teoria da secularização já citada (HERVIEU-LÉGER, 2008) e outro é a análise filológica de Lenaers (2010). Afirmam esses autores que a religião - e mais propriamente o catolicismo romano, no caso de Lenaers - não está condenada ao desaparecimento, mas sim a uma real mudança de perspectiva. Ao deixar-se tomar pela modernidade, o fiel vê as formulações pré-modernas desmoronarem e é então obrigado a optar entre uma "fé moderna" (LENAERS, 2013)99, ou abandonar toda crença. Esta é a realidade do jovem ao ingressar na universidade e entrar em contato direto com o pensamento moderno que está na base da ciência, da tecnologia e da filosofia. A pesquisa deixa claro que de fato muitos jovens deixam a religião na qual foram criados, embora a maioria conserve alguma forma de

\footnotetext{
${ }^{9}$ Ao falar de "fé moderna", R. Lenaers situa-se na perspectiva teológica de D. Bonhoeffer, que em suas cartas da prisão diz ser preciso viver "como se deus não existisse". A fé num deus extramundano, eterno e todo-poderoso, que é o objeto de culto do cristianismo medieval, perde plausibilidade diante da modernidade. Para que a fé cristã tenha sentido no mundo contemporâneo é necessário que se elaborem outras formulações linguísticas. Sobre isso versa o cap. 1 de LENAERS (2013).
} 
espiritualidade. Este foi, aliás, um dos objetivos da pesquisa: entender a realidade religiosa dos estudantes para proporcionar-lhes uma formação adequada e estruturas de apoio, como é missão de uma universidade católica. Deixemos, porém, esse tema prático e voltemos a atenção para a questão geral de como estudantes universitários que se declaram cristãos lidam com sua respectiva Igreja.

Os dados da pesquisa somente permitem afirmar com certeza que é um pequeno número de católicos e uma proporção razoavelmente maior de evangélicos que praticam sua religião conforme os preceitos de sua Igreja. Para ir além dessa constatação e retirar da pesquisa uma resposta sobre a "fé moderna", seria necessário investigar as formas não-institucionais de expressão da fé cristã - e isso requer outro instrumento de pesquisa que não um questionário ora utilizado, estruturada sobre questões "fechadas".

O questionário permite, porém, apontar uma das condições de possibilidade de produção daquela "fé moderna": a relação positiva com lideranças de sua comunidade religiosa. Embora, como já foi dito, a expressão "líder da sua comunidade religiosa" possa dar ensejo a ambiguidade de interpretações, com certeza ela expressa a confiança na/s pessoa/s que está/ão à frente de sua Igreja. Todos os atributos dessa liderança foram vistos positivamente, de modo especial pelos evangélicos. Vale a pena reproduzi-los: (1) conhecem bem a doutrina e são pessoas preparadas teológica e culturalmente; (2) têm bom relacionamento e acolhem bem as pessoas (3) são pessoas de oração, de espiritualidade e sabedoria; (4) são bons celebrantes e fazem bonitos cultos/reuniões, com muito louvor e oração; (5) Estão preocupados com os valores espirituais e transcendentes e em combater os valores mundanos; (6) vivem com coerência e ética o que pregam/ensinam; (7) exercem uma liderança democrática com a participação dos membros; (8) são lideranças que não se preocupam com bens materiais e dinheiro; e (9) procuram relacionar a religião com a dimensão social, ecológica e política. 
Essa relação pessoal com líderes religiosos de sua comunidade (não somente padres e pastores, mas também dirigentes de grupos ou movimentos) parece ser o principal vínculo de muitos jovens com a Igreja, principalmente entre os católicos que pouco frequentam os atos de culto coletivo. $\mathrm{O}$ fato da relação ter um caráter pessoal - embora a pessoa tenha função institucional de liderança - parece contrabalançar as discordâncias entre as crenças e proposições comportamentais oficialmente apresentadas pela instituição religiosa. Sentindo o apoio de uma liderança religiosa em quem confia, o jovem universitário sente-se desobrigado de seguir rigorosamente as doutrinas e normas eclesiásticas sem contudo desligar-se da sua Igreja nem abrir mão de uma "fé moderna". Isso fica bem claro no caso dos católicos que em grande proporção reconhecem seguir a religião à sua maneira. A partir dessa pista será menos trabalhoso pesquisar o processo atual de elaboração de uma "fé moderna” entre a população universitária.

\section{Conclusão}

O pluralismo e o trânsito religioso parecem mesmo fazer parte do dia a dia das pessoas e das instituições religiosas da atualidade. Nela convivem afeição e desafeição às instituições. Fica evidente o interesse pelo tema religioso. A passagem do pequeno mundo familiar para o mundo universitário é uma mudança real e deve continuar a despertar a atenção da universidade, de modo especial no que se refere aos temas da identidade e da transmissão religiosa. A grande maioria dos estudantes disse ter interesse em dar educação religiosa a seus filhos, porém não foi perguntado se seria sobre sua tradição religiosa específica. Também chama a atenção o grupo dos sem religião que apresenta crescimento a cada ano e em todas as pesquisas, seja local, nacional ou internacional. ${ }^{10}$ Isso sinaliza que as instituições religiosas deverão mudar suas formas de atuação para conseguirem continuar existindo socialmente e de forma significativa.

\footnotetext{
${ }^{10}$ Ocupam o terceiro lugar nos três índices: local, nacional e internacional. Pesquisa local coordenada por Malco Camargos (2012) e dados apresentados por Pedro R. A. Oliveira (2013) e Roberlei Panasiewicz (2013). Dados da pesquisa nacional apresentados pelo IBGE (2010). Dados internacionais apresentados por Faustino Teixeira (2013, p. 19).
} 
A pesquisa realça inequivocamente a importância dos líderes religiosos ante a formação de seus adeptos. Para além de consolidar uma espiritualidade humanizante, há desafios no sentido de suscitar maior tolerância, valorização da diferença e contribuição para a construção da cultura da paz. Necessidades exigidas pela sociedade contemporânea que também querem sustentabilidade e maior consciência planetária.

Essas proposições se confirmam na análise comparativa entre católicos e evangélicos. Somando, essas duas denominações são responsáveis pela grande maioria dos estudantes da PUC Minas, mas também no Brasil, segundo o Censo 2010. Tanto fiéis de uma quanto de outra sinalizam interesse em passar os valores religiosos para seus filhos. A pesquisa mostrou maneiras diferentes de católicos e de evangélicos lidarem com o religioso e com práticas ditas cristãs: diferenças na maneira como atualizam seus conhecimentos religiosos, como avaliam seus líderes, como pensam temas religiosos e disciplinares. Traço comum e que se destaca é a importância atribuída ao líder. Mesmo não sabendo se a resposta foi tendo como referência o líder local ou o que tem reconhecimento social, tanto católicos quanto evangélicos prezam por sua valorização.

A pesquisa sinaliza, por um lado, a afeição que os jovens têm pelo religioso e, por outro lado, a desafeição que têm em relação às instituições religiosas. Um desafio especial que se instala aos que ocupam lideranças corresponde à escuta de seus adeptos e suas demandas religiosas. A pergunta que permanece e que desafia o tempo está em saber se é possível criar afeição religiosa institucional. 


\section{REFERÊNCIAS}

BAPTISTA, Paulo Agostinho (Coord.). Relatório da Pesquisa "Perfil do Estudante da PUCMG". Horizonte, Belo Horizonte, v. 11, n. 31, p. 1275-1314, out. 2013. ISSN 2175-5841. Disponível em:

<http://periodicos.pucminas.br/index.php/horizonte/article/view/5904/5624>. Acesso em: 10 ago. 2014.

BERGER, Peter. O dossel sagrado. São Paulo: Paulinas, 1985.

BERGER, Peter L.; LUCKMANN, Thomas. A construção social da realidade. 4. ed. Petrópolis: Vozes, 1978.

CAMARGOS, Malco (Coord.). Valores e religião na região metropolitana de Belo Horizonte. Belo Horizonte: Vertex Pesquisa, 2012.

ELIADE, Mircea. O sagrado e o profano: a essência das religiões. São Paulo: Martins Fontes, 2001.

DURKHEIM, Emile: Les formes élémentaires de la vie religieuse. 4. ed. Paris: P.U.F., 1960.

GEFFRÉ, Claude. Crer e interpretar: a virada hermenêutica da teologia. Petrópolis: Vozes, 2004.

HERVIEU-LÉGER, Danièle. O peregrino e o convertido: a religião em movimento. Petrópolis: Vozes, 2008.

IBGE. Censo 2010. Disponível em: <http://www.ibge.gov.br/home/presidencia/ noticias/noticia_visualiza.php?id_noticia=2170\&id_pagina=1>. Acesso em: 12 ago. 2014.

JAYANTH, M. De la pluralidad al pluralismo. Selecciones de Teología, Barcelona, n. 163, v. 41, 2002.

LENAERS, R.: Outro cristianismo é possível: a fé em linguagem moderna. São Paulo: Paulus, 2010. Coleção Tempo Axial.

LENAERS, Roger: Viver em Deus sem Deus? São Paulo: Paulus, 2013. Coleção Tempo Axial.

OLIVEIRA, Pedro A. Ribeiro de. Pertença/desafeição religiosa: recuperando um antigo conceito para entender o catolicismo hoje. Horizonte, Belo Horizonte, v. 10, n. 28, p. 1230-1254, out./dez. 2012. Disponível em:

<http://periodicos.pucminas.br/index.php/horizonte/article/view/P.21755841.2012v10n2 8p1255/4657>. Acesso em: 10 ago. 2014. 
PANASIEWICZ, Roberlei. Categorização de experiências transcendentais: uma leitura da religiosidade, da fé e da religião. Revista Pistis e Práxis, Curitiba, v. 5, n. 2, p. 587-611, jul.-dez. 2013. Diponível em: <file://C:/Users/Roberlei/Downloads/pistis12365\%20(4).pdf>. Acesso em: 12 ago. 2014.

PANASIEWICZ, Roberlei. Religião e Catolicismo em Belo Horizonte: dados de pesquisa e leitura teológico-pastoral. Horizonte, Belo Horizonte, v. 10, n. 28, p. 1255-1279, out./dez. 2012. Disponível em: <http://periodicos.pucminas.br/ index.php/horizonte/article/view/P.2175-5841.2012v10n28p1230/4656>. Acesso em: 10 ago. 2014.

RIBEIRO JUNIOR, Jorge Claudio Noel. Juventude e religião. Diversidade e autonomia. In: OLIVEIRA, Pedro A. Ribeiro e MORI, Geraldo de. Mobilidade religiosa: linguagens, juventude, política. São Paulo: Paulinas/Soter, 2012.

RODRIGUES, Solange dos Santos. Jovens, experiência do sagrado e pertencimento religioso: um olhar sobre a literatura. In: OLIVEIRA, Pedro A. Ribeiro e MORI, Geraldo de. Mobilidade religiosa: linguagens, juventude, política. São Paulo: Paulinas/Soter, 2012

TEIXEIRA, Faustino. O Censo de 2012 e as religiões no Brasil: esboço de apresentação. In: TEIXEIRA, Faustino; MENEZES, Renata (Orgs.). Religiões em movimento: o Censo de 2010. Petrópolis: Vozes, 2013. 